\section{Technologia strawbale. Pensjonat w Paleokastro}

\section{Strawbale technology. Guest house in Paleokastro}

\section{Streszczenie}

Artykuł przybliża technologię strawbale oraz uzasadnia konieczność prowadzenia szerokiej edukacji w tym zakresie. Przy kład studenckiego projektu dyplomowego pokazuje możliwości jakie daje budownictwo naturalne, wskazuje na korzysci dla d w nurt rozwoju zrównoważonego.

\section{Abstract}

The article familiarises readers with straw-bale technology and justifies the necessity of conducting broad education efforts in this field. The
example of a student's diploma design project shows the possibilities offered by natural construction and points to benefits to health and well-being, as well as the environment. Apart from discussing the aspect of environmental protection, it also focuses on the economic and social aspect. It is thus in line with sustainable development.

Stowa kluczowe: technologia, strawbalp, pense, Crete

\section{WSTĘP}

Coraz częściej zadajemy sobie pytanie czy rozpędzony postęp technologii daje odpowiedź na problemy ekologiczne i społeczne, z jakimi obecnie boryka się świat? Może warto spojrzeć wstecz na sprawdzone metody budowania naszych przodków i starać się wykorzystywać je do kształtowania wspótczesnego środowiska zbudowanego. Architekt powinien być wrażliwy na te kwestie i starać sie w swoich projektach świadomie ksztattować ista fragment budynku by ten nie miał negatywnego wptywu frag dardo daturych rozwazn jost bu natur

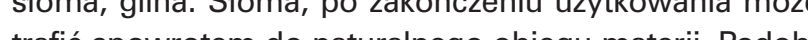
trafic spow so do po zakonczelu uzykowanta moze nie jest z drewnem czy glina. Transport i produkcja kostek stomy - strawbale pochlania mniejszą ilosc energi niz w przypadku konwencjonalnych surowcow. Dlatego sposob wz znany od wiekow, jest nieszkodliwy dla środowiska. Ponadto, mikroklimat $\mathrm{w}$ domu wybudowanym $\mathrm{z}$ naturalnych materiałów jest o wiele zdrowszy dla mieszkańców. Mimo tych wszystkich zalet, ten rodzaj budownictwa spotyka się wciąż z niezrozumieniem i uprzedzeniami ludzi. Szerzeniem wiedzy i uswiadamianiem spoleczenstwa zajmują się organizacje takie jak Cohaitat', OSBN(w Polsce) ${ }^{2}$ ASBN w Austrii ${ }^{3}$ czy Minoeco (na Krecie) ${ }^{4}$.

\section{INTRODUCTION}

We increasingly often ask ourselves whether the rapid progress of technology provides the answer currently facing. Perhaps it would be worth it to look back towards proven construction methods used by our ancestors and attempt to use them to shape the contemporary built environment. Architects should be sensitive to these matters and try to consciously shape every part of a building in their designs, so tha said building will not have a negative impact on the surroundings and users. Architecture that utilises natural materials that are locally available, such as timber part of the natur cycle, of morter. The mecter is imilar with timber cray. Straw-bal. phe matter is transport consumes a lower amount of energy when compared to conventional resources. This is why erecting buildings using straw-bale, which has been known for centuries, is more environmentally friendly. Furthermore the microclimate inside a house buit from natural materials is much healthier for residents. Despite all of these advantages, this form of construcagainst it. Organisations such as Cohabitat', OSBN (in of (rete) $)^{4}$. work towards spreading knowledge and aising public awareness in this regard. to ecological and social problems that the world is Straw and clay, is an alternalive to standard solutions. tion is still misunderstood, with many being biased Poland) ${ }^{2}$, ASBN in Austria ${ }^{3}$ or Minoeco (on the island

\section{TECHNOLOGIA STRAWBALE}

słomy [1]

Nurt strawbale łączy w sobie nowoczesne projetowanie $z$ tradycyjnymi metodami. Tego rodzaju budownictwo było znane i stosowane od wielu dekad i wykazywało sie skutecznościa i trwałościa przez stulecia. Jego poczat siegaja XIX wieku i wiążą sie z wynalezieniem pras do siana i stomy w USA. Wtedy to mieszkańcy stanu dabraska w rejo w UA. Wills zaczeli wznosić swoje danu $\mathrm{Na-}$ używajac kostek słomy jako elementu nóńne. Tak rodzaj konstruowania budynków do dzisiaj nazywany

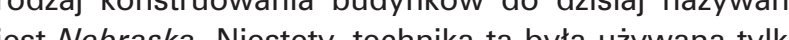
jest Nebrask. N Nestety, technika ta byla używana tylko lok najersze zapomnian i w drugiej polowie XX wieku. Najstarsze zachowane i uzy kowane do dzis domy wzniesiono w lat 1915-1930 pr, np. Fawn Lake Ranch Whyan is. Lata 1915-1930 przy hosy najwięsze rozpowszechnienie metody. Europa równieź może się poszczycic doswiadczeniem we wznoszeniu budynkow w tej technologii. W 1921 roku w Montragis we Franci powstał budynek o konstrukcji drewnianej z wypełnieniem z kostek słomy. Budynek znany jest pod nazwa Maison Feuilete i jest najstarszym tego rodzaju obiektem w Europie. W pierwszej połowie XX w., technolog strawbale uzywano rowniez w Holandii i Niemczech. Je rozwój, ktory nastąpił w połowie XX wieku spowodowa że tradycyjne metody straciły na atrakcyjności. Rene sans naturalnego budownictwa nastąił $w$ latach 80 . XX i miał związek z szeregiem publikacji dotyczących tego tematu, wydawanych wtedy w USA. W 1993 roku zacze to wydawać kwartalnik The Last Straw - the journal of straw - bale construction. Nagły wzrost zainteresowania tematem wiązał się z powstaniem licznych obiektów $z$ naturalnych materiałów. Liczba tych budynków była na tyle duża, by pojawity sie pierwsze regulacje prawne dotyczace budowania ze stomy. W latach 80. XX wiku zaczeto też prowadzić badania i warsztaty, podczas których testowano różne rozwiazania i eksperymentowan y technika bu 1993 roku odby sie piewano 作

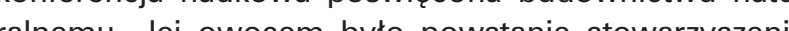
Natural Straw Bale Research Advisory Network. Orgaizacja staw Bale Research Advison Network. Organizacja ta dala poczatek wielu międzynarodowym stowarzyszeniom dzialającym do chwill obecnej, których elem jest promowanie alternatywnego rodzaju budownictwa.

2.2. Zalety technologii strawbale i wątpliwości z nia związane $[4,5]$

Naturalne budownictwo oparte jest na wykorzystaniu surowców wzrastających corocznie i łatwo dostępnych. Sciany z izolacją termiczną w postaci kostek słomy mogą uzyskac parametry współczynnika przewodzenia ciepła odpowiednie dla domów energooszczędnych, a nawet pasywnych. Jednak najważniejszy jest aspek zdrowotny. W domu z materiałów niskoprzetworzonych naturalnego pochodzenia, mikroklimat jest o wiele ko-
2. STRAWBALE TECHNOLOGY

2.1. Historical outline of straw-bale construction [1] Straw-bale combines modern design with traditiona methods. This type of construction has been know and utilised for many decades, demonstrating effectiveness and durability for centuries. Its beginnings date back to the nineteenth century and are associated with the invention of the straw press in the United States of America. It was then that residents of the state of Nebraska, in the area of Sand Hills, began to build their houses using blocks of straw utilised in the role of a load-bearing element. This type of building is today called the Nebraska. Unfortunately, this techique had only been used locally and was forgotten surviving years 1900-1914, The years 1915-1930 brought with them a significant spread in the method's use. Europe can also pride itself in experience in erecting buildings using this technology. In 1921 in Montragis, France, a building with a timber structure and straw-bale infill was built. The building is known under the name Maison Feuilete and is the oldest building of this type in Europe. In the first half of the twentieth century straw-bale technology was also used in the Netherlands and in Germany. Its development, which took place in the middle of the twentieth century, caused traditional methods to lose their attractiveness. A renaissance of natural construction took place in the 1980's and was associated with a series of publications on this subject that were published at the time in the US. The year 1993 saw the start of the issuing of The Last Straw-the journal of straw-bale construction, a quarterly. The sudden increase in interest in the subject was associated with the construction of numerous buildings out of natural materials. The number of these buildings was large enough that the first legal regulations concerning straw-bale construction have started to appear. Studies and workshops during which construction technology was experimented with started to be conducted in the 1980's. In 1993 the first scientific conference on natural construction took place. Its result was the founding of the Natura Straw Bale Research Advisory Network. This organisation gave rise to many international associations
that operate to this day and whose goal is the promotion of alternative types of construction.

\subsection{Advantages of straw-bale technology and}

\section{doubts associated with it $[4,5]$}

Natural construction is based on making use of resources that grow each year and are easily accessible. Walls with straw-bale thermal insulation can reach thermal conductivity parameters required of energy-efficient and even passive buildings. However, the aspect of health is key. Interior microclimate in a house made from natural materials that undergo low levels of processing is much more beneficial when compared to buildings built out of artificial materials. The properties of clay plasters, which regulate 
rzystniejszy, niż w budynkach wzniesionych przy użyciu sztucznych materiałów. Niebagatelne są również właściwości tynków glinianych, które regulują poziom wilgotności w pomieszczeniach. Ma to duży wpływ na ograniczenie rozwoju alergii, drobnoustrojów czy pleśw wielu ludziach wanie przy użyciu kostek słomy budzi pewność powoduje kwestia bezpieczeństwa pożarowe go. Luźna stoma zapala sie bardzo szybko i ptonie intengo. Luź pow so

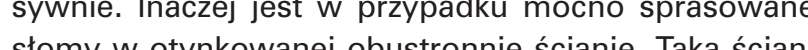
słomy w otynkowanej obustronnie scianie. Taka ścian może nawet osiągnąc odpornosć ogniową do 90 minut (REI 90). Kolejna kwestią jest wyobrażenie o ścianach z słomy jako idealnym miejscu zamieszkania przez myszy tów gyzonie. Tu stoma nie roźni się od innych materiatów izolacyjnych, takich jak welna drzewna, czy mineralna, ktore równibż stanowią arakcyjne miejsce do założenia gniazda przez polne zwierzęta. Można się przed tym uchronic, stosując odpowiednie siatki zabezpieczające, czy tynk. Często obawy budzi równieź powstawanie grzybów i pleśni na kostach słomy. Jeżeli ściany zaprojektowane są zgodnie z zasadami fizyki budowli, a do ich wzniesienia użyte będą suche kostki (których wilgotność nie przegracza $13 \%$ ), nie ma ryzyka wystąpienia tego rodzaju problemu. Trzeba pamietać o tym, by zewnętrzna warstwa tynku była bardziej paroprzepuszczalna niż wewnętrzna, dzięki czemu para będzie mogła dyfundowac na zewnątrz ściany. Niekorzystne jest stosowanie tynków cementowych, gdyż ograniczają one dyfuzyjnośc i mogą doprowadzić do powstawania punktu rosy wewnątrz ściany.

2.3. Techniczne aspekty budownictwa $z$ kostek słomy Budownicto 2015 rokuralnego udato sie przeprowadzić badania wspótczynnika przewodzenia ciepla kostek stomy w Instytucie Techniki Budow w Inskać dle Trzecty uzyskac dla przeplywu ciepla wzdluz todyg słomy przy ściany o grubo sciany o grubs kiem gliepła $U$ ox 0,16 W/mK, co odpowyda parametrom wymaganym przy budownictwie energooszczędnym

Obustronnie otynkowana sciana z kostek słomy określona została przez normy niemieckie jako materiał trudno zapalny (B1). W 2014 roku przeprowadzono w Niemczech test odpornosci ogniowej na scianie o konstrukc szkieletowej z wypełnieniem z kostek słomy i obustronnym pokryciem osmiomilimetrową warstwą tynku wapiennego. Sciana wytrzymała symulację pożaru przez 90 min (REI 90), zachowując szczelność, izolacyjność ogniową, a także nośność

Zawilgocenie budynku może być efektem działania deszczu, kondensacji pary wodnej pochodzącej z wnętrza obiektu lub też podciągania kapilarnego z gruntu. Są sprawdzone sposoby, dzięki którym można zapobiec tym problemom. Przeciwko podciąganiu kapilarnemu humidity levels in interiors, are also not without imdevelopment of aldgies or the growth of microorganisms or mould. However, many have doubts and fears associated with straw-bale construction. The matter of fire safety is most often cited as a cause of these fears. Loose straw catches fire very quickly and burns intensively. Compressed straw with both of its sides covered in plaster, however, produces completely different results. Such a wall can reach a fire resistance of 90 minutes (REI 90). Another matter is the popular image of straw walls as the idea home for mice and other rodents. Here straw-bale does not differ from other insulation materials such as wood or mineral wool, which also provides attracive pla sor small anit, which a nest in. However, we ate safety meshes or plasters. There are aften fears bout the appearance of fungi or mould on strawbales. Provided that walls have been designed in accordance with the principles of building engineering physics and that dry straw-bales (whose moisture content does not exceed 13\%) were used in the construction, there should be no risk of this problem appearing. We should also remember that the external layer of plaster should feature greater water vapour permeability than the internal one, which will enable vapour diffusion outside of the wall. The use of cement plasters is not advised as they limit the capacity for diffusion and could lead to the appearance of a dew point within the wall.

2.4. Technical aspects of straw-bale construction Towards the end of 2015 the Polish Association for Natural Construction managed to perform research on heat transfer coefficient values of straw-bales at the Polish Institute of Construction Technology. The result that was obtained for heat flow along straw stalks with a density of around $100 \mathrm{~kg} / \mathrm{m} 3$ was $\lambda d=0,073 \mathrm{~W} / \mathrm{mK}$. This results in a $U$ heat transfer coefficient of around $0,16 \mathrm{~W} / \mathrm{m} 2 \mathrm{~K}$ for a $40-\mathrm{cm}$-thick wal with both of its sides covered in clay plaster, which corresponds to parameters required of energy-efficient buildings. A straw-bale wall plastered with clay ial (B1) by German sterdards. A fire radant matehal (B ) by German standards. A fire resistance test wall with straw with a layer of lime plaster. The wall withstood a fire simulation for 90 minutes (REI 90) maintaining tighthess, insulation and load-bearing capacity in the conditions of a fire. A building can become damp due to the effect of rain, the condensation of water vapour originating from inside the building or through capillary action drawing water from the soil. There are proven methods that can be used to prevent these problems. A horizontal waterproofing layer in the form of bituminised coating is used to prevent capillary action. In the case of buildings without a cella it is also recommended to raise its floor level, forming a ventilated space between the soil and the floo stosuje się standardowo poziomą izolację w postaci np. powłoki bitumicznej. W przypadku obiektów niepodpiwniczonych zaleca się również podniesienie poziom budynku, tworząc wentylowaną przestrzeń pomiedzy gruntem a posadzką. Przed odpryskującą wodą deszczową ściany powinny być chronione na wysokośc przynajmniej $30 \mathrm{~cm}$ ponad powierzchnia gruntu czy stropodachu. Dobrym rozwiazzaniem jest również stosowa nie opaski żwirowej wokół budynku. Kondensacii pary no opaski żw warstwach ściany zapobiega odpowiednie wodnej $w$ warstwach sciany zapobiega odpowiednie ułożenie warstw $i$ dobór materialów tak, aby zewnętrzn Unoż ini to swobodny przeptyw pary wodnej zętrzna. Wh budy to swa zew słomy.

\section{GABRIELA'S GARDEN W PALEOKASTRO [2], [3]}

$W$ technologii strawbale postanowiono zrewitalizowa zespół pensjonatowo - restauracyjny w Paleokastro n Krecie. Podstawą do stworzenia projektu tego zalożenta były warsztaty budowlane, które odbyły się w październiku 2015 r. Organizatorami wydarzenia było greckie stowarzyszenie Minoeco we wspólpracy z austriack grupą ASBN ( Austrian Straw-Bale Network). W efekcie powstał projekt, ktorego częsc urbanistyczna zostala opracowana w dwuosobowym zespole. Obejmuje on zagospodarowanie dziatki należącej do Gabrieli Damianakis. Cały kompleks wkomponowany jest w otaczajacą przyrodę - wzgórze oraz bujną zieleń. Lokalizacja ma duży potencjał turystyczny. Ze względu na zły stan techniczny istniejacych na działce obiektow, zaproponowano nowe rozwiązania architektoniczne i aranżację teren z poszanowaniem dla pierwotnej kompozycji. W skład projektowanego zespołu wchodzą dwa nowe budynki: pensionat oraz tawerna powiazane ze soba założeniem ogrodowym (Gabriela's Garden).

\subsection{Lokalizacja}

Gabriela,s Garden znajduje się w miejscowości Paleokastro na Krecie - największej greckiej wyspie położonej na Morzu Śródziemnym. Ta niewielka miejscowośc ma bezpośredni dostep do morza i usytuowana jest na północnym wybrzeżu $w$ centralnej części rozciagajacej się równoleżnikowo wyspy. Dzięki swojej lokalizaci uwarunkowaniom naturalnym, Paleokastro ma wyjat kowy, lecz niewykorzystany potencjat turystyczny. Kreta to czwarta największa wyspa na Morzu Śródziemnym Wlatach 3000 - 1500 p.n.e. rozkwilla tu Kultu ma minojska, która mocno wpłynęła na rozwój cywilizacji w całej Europie. Następnie Kreta przechodzila w posiadanie Cesastwa Bizantyjokiego, arabskie, weneckie oraz Imperium Osmańskiego. Pod koniec XVIII wieku odzyskała niepodległośc, lecz niedługo poźniej przeszła pod władani tureckie, a następnie egipskie. Dopiero na początku XX w. Kreta została na stałe włączona do Grecji. Niezwykle ciekawa i bogata historia, sprawila, ze na wyspie można znaleźć liczne ślady działalności różnych kultur i ludôw. slab. Walls should be protected against rainwater spraying to a height of at least $30 \mathrm{~cm}$ above ground is the building of a gravel bed around the building Water vapour condensation within the wall's layers can be prevented by an appropriate placement of layers and material selection so that the external laye will have a lower diffusion resistance than the interna one. This will enable the free flow of moisture from the interior to the exterior of the building withou condensation inside straw-bales.

3. GABRIELA'S GARDEN IN PALAIOKASTRO [2, 3] A decision was made to revitalise a guesthouse and restaurant complex located in Palaiokastro, Crete, usent of a design of this complex was provided by . ber 2015. The event was organised by the Greek Mnoeco association in cooperation with the Austrigroup called ASBN (Austrian Straw-Bale Network). As a result, a design was developed, whose urban section was prepared in a two-person team 5 . It in cludes site development of a lot belonging to Gabriela Damianakis. The entire complex was blended into the surrounding natural environment-a hill and lush greenery. The location has significant potential to become a tourist destination. Due to the poor technical condition of the structures that had been present on site, new architectural solutions and site development was proposed while respecting the origina composition. The newly designed complex includes two new buildings: a guesthouse and a tavern that are connected with a garden composition (Gabriela's Garden)

\subsection{Location}

Gabriela's Garden is located in the town of Palaiokastro, Crete-the largest Greek island, located on the Mediterranean Sea. This small town has direct access to the sea and is located on the northern coast of the island, in the central part of its longituand natural conditions, Palaiokastro has a unique, yet untapped tourism potential. Crete is the fourthlargest island of the Mediterranean Sea. In the pethe flourishing Minoan culture which has had a profound impact on the development of civilisation in all of Europe. Afterwards, Crete changed ownership, being in Byzantine, Arab, Venetion and Ottoman hands. It gained independence towards the end of the eighteenth century, but found itself under Turk ish and later Egyptian rule shortly after. It was only in the twentieth century that Crete was incorpor on into Greece. The extraordinarily interesting and rich history of the island has resulted in the fact that we can find numerous traces of the activity of various cultures and peoples here. Thanks to these conditions, one of the main pillars of Crete's economy is tourism. The site covered by the design lies at on 
Dzięki tym uwarunkowaniom jednym z głównych filarów gospodarki Krety jest turystyka. Projektowana działka leży przy jednej z dwóch głównych ulic prowadzących przez Paleokastro, w niewielkiej odległości od plaży i wyjazdu na drogę szybkiego ruchu przebiegającą przez miejscowość $w$ formie wiaduktu. Powierzchnia działki to $12491 \mathrm{~m}^{2}, \mathrm{z}$ czego ponad połowe zajmuje strome południowe zbocze północnego pasma gór okalających wioske. Od strony południowej i zachodniej przylega ona do skę. Od zaś od strony wschodniej sasiaduje z istniejący zabudowaniami.

\subsection{Uwarunkowania naturaln}

Klimat wyspy określa sie jako półsuchy, lecz w ciagu roku wyróżnia się dwie główne pory: zimną i wilgotną od października do marca oraz gorąca i suchą od kwietnia do września. Ze względu na mocno zróżnicowane ukształtowanie terenu wyspy, występuje tu wiele wariacji klimatycznych, w zależności od uwarunkowan naturalnych i wysokości nad poziomem morza. W miesiącach letnich srednie temperatury powietrza sięgają nawet $26^{\circ} \mathrm{C}$ a w zimowych spadają do około $10^{\circ} \mathrm{C}$. Paleokastro leży na pớnocnym wybrzezu Krety $w$ terenie górzystym. Centrum miejscowości położone jest $w$ dolinie, lecz ze względu na charakter otoczenia, część zabudowa znajduje się na trudno dostępnych stromych zboczach. Zimą, w czasie pory deszczowej, jedna z głównych ulic staje się ciekiem wodnym odprowadzającym do morz wody opadowe spływające z gór. Charakterystyczne dla tej części wybrzeża są wysokie, skaliste klify i małe kamieniste plaże, co skutkuje dużą czystością i przejrzystością otaczających je wód.

3.3. Komunikacja
Nad Paleokastro przebiega droga szybkiego ruchu będąca głównym ciągiem komunikacyjnym wyspy łączącym jej wschodni i zachodni kra ponad ponad nym o zal nym o zaledwie $5 \mathrm{~km}$ Heraklonie (raklon) zhajduje się zarórych port morski jaki iduzy port lo niczy, za pomoca któnch mozna dost sie na wyse. Druge duze lotnisko usytuowane jest wh się także główna trasa łącząca północ i południe wyspy.

\subsection{Turystyka}

Wszystkie wymienione uwarunkowania Paleokastro stanowia niezaprzeczalne walory dla rozwoju turystyki n tym obszarze. Klimat i usytuowanie sprzyjają letniem wypoczynkowi nie tylko na malowniczo usytuowane między klifami plaży w samej miejscowości, ale także na licznych pobliskich nadbrzezach. Zachęcają takze do wycieczek górskich i poznawania ciekawej śródziemnomorskiej przyrody. Dzięki przebiegającej nad Paleokastro drodze szybkiego ruchu i dobrze rozwiniętej komunikacji of the two main roads that run through Palaiokasrapid transit road that runs through the the an overpass. The lot's surface area amounts to 12 $491 \mathrm{~m} 2$, over half of which is taken up by the steep southern slope of the northern mountain range tha surrounds the village. From the southern and westn side it borders on roads, while from the eas there are adjacent buildings.

\subsection{Natural conditions}

The climate of the island is described as semi-arid however, two major seasons can be distinguished throughout the year: a cold and humid season from April and September. Due to the highty varied ter f the is Sert num ent here tion above sea level. In summer months, mean air to they drop to about $10 \mathrm{oC}$. Palaiokastro is located on the northern coast of Crete in a mountainous a The town's centre is located in a valley, but due to the character of its surroundings some of the buildings are on poorly accessible steep slopes. In winter, during rain season, one of the main streets becomes a waterway that drains surface runoff flowing down from the mountains. Tall rocky cliffs and beaches are characteristic for this part of the island, which results in the waters that surround them to be clean and clear.

\subsection{Circulation}

Above Palaiokastro there is an expressway, which is the island's main circulation trail, connecting its eastern and western tips and major cities: Heraklion, Rethymno, Chania, Malia and Sitia. It runs above the town in the form of a tall overpass that connects the hills around Palaiokastro. In Heraklion (Iraklion), lo cated only $15 \mathrm{~km}$ away, there is both a seaport, as well as a large airport, which one can use to get to he island. A second large airport is located in Chania, which is around $130 \mathrm{~km}$ away from the town. The main road connecting the north and south of the island is located a small distance away from Palaio-
kastro.

\subsection{Tourism}

All of Palaiokastro's abovementioned characteristics constitute undisputable assets in terms of tourism development in the area. Climate and location are conducive to summer recreation, not only on the beach that is picturesquely situated between cliffs in the town itself but also near the numerous nearby shores. They also encourage one to go hiking and explore the interesting Mediterranean environment Thanks to the expressway that runs above Palaiokastro, as well as the well-developed transport network we can easily reach the largest of Crete's cities tha are replete with historical sites and tourist attraction straight from the town. In nearby Heraklion we ca
W łatwy sposób można dostać się z miejscowości do najturystyczne. W pobliskim Heraklionie można zobaczyc przede wszystkim ruiny pałacu w Knossos - pozostatości po rozkwitającej tu kulturze minojskiej oraz $\mathrm{Mu}$ zeum Archeologiczne wyposażone w bogate i bezcenne zbiory dokumentujące rozwój pierwszej cywilizaci europejskiej. Zarówno w Heraklionie jak i w Rethymo oraz Chani można zobaczyć średniowieczne fortyfika cje i porty weneckie. Wieksze miejscowości zacheca cje i porty moznackie. Więcsze miejscowości zachęcaja kulturowej różnorodności, spacerów po nadmorskich kulturowej roznorodnosci, spacerow po nadmorskich in

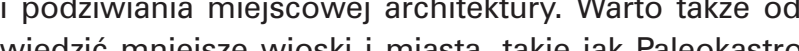
wiedzí mín by zakosztowac prawdziwego klmatu wyspy oraz sprobowac miejscowy hy wrobów od lokalnych rolników m.in. wina, serów i oliwy z oliwek.

\section{NOWY ZESPÓŁ URBANISTYCZNY GABRIELA'S}

\section{GARDE}

Obecnie na działce zespołu Gabriela's Garden znajduje się pięć obiektów $w$ bardzo złym stanie technicznym. Zostały one zbudowane w latach 1978-1983 przez ojc obecnej właścicielki - Gabrielli Damianakis. W skład zespołu wchodzą trzykondygnacyjny hotel, tawerna oraz budynki gospodarcze, wszystkie wybudowane z nieocieplonego betonu z drewnianą nieszczelną stolarka oknami jednoszybowymi i kamiennymi posadzkami bez odpowiedniej wentylacji i centralnego ogrzewania W związku z opuszczeniem terenu na piętnaście lat pod koniec lat 90. , obiekty popadły w ruinę i obecnie jedynie hotel jest użytkowany, lecz powinien on przejść gruntowny remont. Reszta budynków nadaje sie do rozbiórki. Cały zespół wkomponowany jest w otaczajaca przyrode - wzzórze oraz bujną zielen.

\subsection{Główne założenia projektowe}

Ideą projektu jest stworzenie propozycji renowacji całego zespołu, tak by wykorzystać niepowtarzalny potencjał tego miejsca z zachowaniem i wyeksponowaniem ego walorów. Generalny plan zakłada pozostawienie pierwotnego budynku hotelu i jego gruntowny remont (przede wszystkim odbudowę drugiego piętra oraz ocieplenie z wykorzystaniem naturalnych materiałów) oraz nową aranżację pozostałej części działki z zachowaniem jej ogrodowego, tarasowego charakteru wpisującego sie w otoczenie. W nowej, zachodniej czesści zaprojektowano dwa budynki w technologii strawbale: tawernę $w$ je pierwotnym położeniu bezpośrednio przy głównej ulicy oraz pensjonat z apartamentami o podwyższonym standardzie. Hotel położony jest wyżej ze względu na wykorzystanie naturalnego uksztaltowania terenu. Obydwa obiekty mają formę nawiązującą do archetypu greckiej architektury: są to białe proste kubiczne bryły z płaskim dachami i drewnianą stolarką w zabudowie tarasowej. Ze względu na planowany charakter zespołu, między see the ruins of Knossos-the remains of the Minoan culture that flourished here, as well as the logical Museum, equipped with a wealth of priceless collections documenting the development of the first European civilisation.

In Heraklion, Rethymno and Chania we can also see Medieval fortifications and Venetian ports. The large towns also encourage us to visit their numerous his torical monuments and discover their cultural diversity, to walk on seaside promenades and picturesque narrow streets and marvel at local architecture. Visting smaller villages and towns like Palaiokastro to taste the island's genuine climate and try the produce also an excellent idea.

\section{THE NEY}

At present, the lot on which the Gabriela's Garden complex was designed is occupied by five buildings in very poor technical conditions. They were built in the years 1978-1983 by the father of the present owner-Gabriella Damianakis. The complex includes of which were built out of uninsulated concrete with untight doors, single-pane windows and stone floors without appropriate ventilation and central heating. Due to the site becoming abandoned for a period of fifteen years towards the end of the 1990's the buildings have fallen into ruin and only the hotel is currently in use. The entire complex is composed into the surrounding natural environment-a hill and lush greenery

\subsection{Main design assumptions}

The main idea behind the design was the formulation of a proposal of the renovation of the entire complex so as to make use of the unique potential of the site while preserving and exposing its assets. The general plan assumed the preservation of the original hotel building and subjecting it to thorough renovation (primarily rebuilding the second storey and insulating it using natural materials), in addition to providing a new arrangement of the remaining part of the site while preserving its gardenthe surbuildings. In the new, wasten section, two new designed: a tavern located at its original location diacent to the main street and a guesthouse with high-standard rooms. The hotel was placed higher due to using the natural shape of the terrain. Both structures have a form that refers to the archetype of Greek architecture: they are simple white cubelike buildings with flat roofs and timber windows and doors, arranged in a step-like manner. Due to the planned character of the complex, a square was formed between the buildings, along with technical and sanitary facilities meant to facilitate the conducting of workshops on natural construction, as well as various other types of events. Its northern 
budynkami powstał plac wraz z zapleczem techniczno - sanitarnym przeznaczony na prowadzenie warsztatów z zakresu budownictwa naturalnego, a także różnorodnych wydarzeń. Jego północną ścianę stanowi mur oporowy powstały w wyniku zróżnicowania poziomów posadowienia budynków. Starą i nową część łączy ogród zaprojektowany $w$ oparciu o dotychczasowe założenia kompozycyjne: dolną część zajmuje wypoczynkowy placyk przenikajacy sie z otaczajaca zielenia przechodzacy w gónej cźści w kaska dow tarasy z wkomponowący w nó w nie poch miá prow Kiaca do platformy widokowej na zboczu wzgiza. Kiery

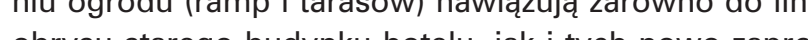
obrysu starego budynku hotelu, jak i tych nowo zaprojektow sych To rozwazzo sprawa, ze cale zalożenie tworzy spojną kompozycyjnie calosc. Od strony południowej, teren jest otoczony bielym murm, charakterystycznym dla budownictwa greckiego.

\subsection{Komunikacja}

Wejścia na działkę znajdują się od strony wschodnie przy starym budynku (w miejscu pierwotnego wejścia) od strony zachodniej przy placu warsztatowym, a takż przy nowo zaprojektowanych obiektach. Glowne wejścia do budynków usytuowane są od strony ulic - do tawerny od głównej drogi, a do hotelu od bocznej drogi wspinającej się na wzgórze. Przy wejściu do obiektu restauracyjnego przewidziana jest rampa dla niepełnosprawnych. Oprócz tego, budynki są dostępne także od wnętrza założenia - tawerna otwarta jest od strony wschodniej na ogród, a od północnej na plac warsztatowy, natomiast do hotelu można dostać sie również od strony ogrodu. Wewnętrzną komunikacje stanowia dwa połaczone ze soba place oraz rampa prowadzaca na taras widokowy usytuowany na zboczu wzgórza. Dla samochodów osobowych przewidziano dwa parkingi jeden we wschodniej czéci dziatki przy starym budyjeden we w w hón

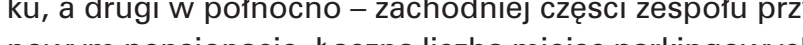
to $16, w$ tym 3 przystosowane do potrzeb osób niepetto $16, \mathrm{w}$ tym
nosprawnych.

\subsection{Zieleń}

Zieleń spełnia ważną rolę $\mathrm{w}$ kształtowaniu całego zespołu. Nie tylko ze względu na jej typowy śródziemnomorski charakter, ale także dlatego, że wpływa ona na poprawe mikroklimatu: $w$ lecie zapewnia odpowiednie nawilzenie suchego powietrza oraz cień pożądany w upalne, słoneczne dni, a zimą ochronę przed deszczem i wiatrem. Założeniem jest pozostawienie jak największej możliwe do zachowania istniejącej roślinności i wkomponowani jej w nowy projekt. Dolną częsć ogrodu otaczają głów nie drzewa oliwne, krzewy oleandrów i róż. Na tarasach wzgórza rosną zarówno mniejsze drzewka jak i zieleń niska - krzewy i trawy. Ponad budynkami występuje pas zieleni z charakterystycznymi dla regionu drzewami karobowymi, a na szczycie znajdują się pojedyncze skupiska wall was formed by a retaining wall built as a result and new section was connected by a garden designed on the basis of the current compositiona layout: the lower part is occupied by a small recreational square that blends with the surrounding greenery and which transforms in its upper section into cascading terraces that incorporate a ramp that leads up to an observation platform on the hillside. The directions adopted in garden solutions (ramps and terraces) refer both to the line of the outline of the old hotel building, as well as to those of newly designed buildings. From the south the site was surrounded with a white

\subsection{Circulation}

Entrances to the lot are located on the eastern side near the old building (in place of the original enrance), from the west near the square for workshops, as well as near newly designed buildings. The main the nearby streets-to the tavern from the side of the main road and to the hotel from the side road that goes up the hill. A ramp for disabled persons was placed near the entrance to the restaurant building Apart from this, buildings are also accessible from inside the complex-the tavern is open from the eas towards the garden, while from the north-towards the square for the workshops. We can also enter the hotel from the garden. Internal circulation is provide by two interconnected squares and a ramp that lead up to an observation deck located on the slope of a hill. Two parking lots were provided for cars-on in the eastern part of the site near the old building and another in the north-western part of the complex near the new guesthouse. The total number of parking spaces is 16 , including 3 spaces for disabled persons.

\subsection{Greenery}

Greenery plays an important role in the design of the entire complex. Not only due to its Mediterranean character, but also because it leads to an improvement in microclimate: in summer it provides appropriate moisture to humidify the dry air an shade desired on hot sunny days, while in winter to leve the greatest possible amount of existing vegetation and making it a part of the new design's composition. The lower part of the garden is primar ily surrounded by olive trees, as well as oleande and rose bushes. Both smaller trees and low-lying greenery-bushes and grasses-grow on terraces on the hill. Above the buildings a belt of greenery was designed with carob trees distinct of the region while at the top there are individual groupings of bushes adapted to the arid climate. Furthermore, the designs of both buildings feature proposals of green roofs which increase the amount of biologically active surfaces and positively affect the ther- sucholubnych krzewów. Ponadto w projektach obydwu chów, które zwiększaja powierzchnię biologicznie czynn oraz wpływają pozytywnie na izolację termiczną budynków - zapobiegaja przed przegrzewaniem dachów najba dziej podatnych na to zjawisko w panującym tam klimacie.

\section{ZROWNOWAŻONY PENSJONAT W TECHNOLOG} STRAWBALE ${ }^{6}$

nsjonat jest budynkiem czterokondygnacyinym, z tarasem na dachu dostepnym dlandygnacynym, z tarasem na dachu dostępnym dla gosci. e ha, rozrzź - posiada on prosta bi

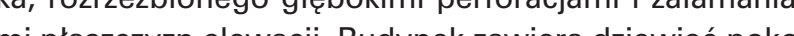
do wyrajecia czesc wspolna rewiea dzieweć pok do wynajęcia, częsc wspólną rekreacyjna oraz strefe techniczną w podziemnej częsci obiektu. Ponsjonat połączony jest z tawerną placem, służącym do organizac
warsztatów i szkoleń.

\subsection{Główne założenia projektowe}

Pensjonat, według zamysłu autorki projektu, ma koic zmysły wypoczywających w nim ludzi, przy jednoczesnym pobudzeniu ich do odczuwania przestrzeni, faktu dźwięków, zapachów towarzyszących przy przebywani w budynku. Aby zapewnić największy komfort ludziom przebywajacym w tak gorącym klimacie, sięgnięto po materiały pochodzenia naturalnego, by budynek nie nagrzewał się, "oddychał", chronit przed hałasem i nie oddziaływał w sposób destrukcyjny na otaczające środowisko. Wykorzystanie słomy jako izolacji termicznej zapewnito naturalną ochronę przed nagrzewaniem sie ścian, co dodatkowo wzmocniło zastosowanie pustk powietrznej dookoła budynku jako bufora cieplnego. Słoma jest także doskonałym izolatorem akustycznym. Zastosowanie tynków glinianych miało zapewnić kom fort oddychania, dzieki noural regulaji wilgotnoś fort oddych pom dzén.

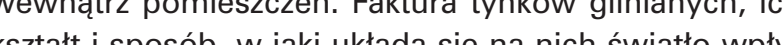
wozt is po wa chodzi z zewetznej stefy budynku do wewnetzogo dziciz ze lstotne w projekce bylo row wez wy dziedzinca. Is ju weje stanie potencjalu wzniesienia i usytuowanie obiektu na tarasowym zboczu, z widokiem na morze i okolicę. Bardzo istotną kwestią bylo wspisanie pensjonatu nie tylko $w$ jego naturalne otoczenie, ale tez kulturowe, z posza nowaniem lokalnego archetypu. Stąd też prosta, kubiczna bryła budynku i użycie bieli. Autorka zaproponował nowoczesną, minimalistyczną interpretację greckiego stylu w celu uzyskania obiektu prostego, lecz niebananego. Budynek powstały $z$ naturalnych organicznych materiałów moze miec nowoczesną formę. Bryła powstała więc w oparciu o przejrzyste proporcje sześkwadratu nadany został również perforacjom elewac czy wewnętrznemu dziedzińcowi. Odsunięcie elewaci mal insulation of buildings-preventing the overheating of roofs which are heavily susceptible to this phenomenon in the local climate.

\section{SUSTAINABLE GUESTHOUSE UTILISING}

STRAW-BALE TECHNOLOGY ${ }^{6}$

The guesthouse was designed as a four-storey building, with a roof terrace available for guests. Its form is a modern interpretation of the local archetypehas a simple white massing in the shape of a cuboid featuring deep perforations and shifts in facade surfaces. The building features nine guest rooms, common recreational area and technical spaces on with the tround level. The guesthouse is connected wis a space for orgaisg workshops and traning courses.

\subsection{Main design assumptions}

.

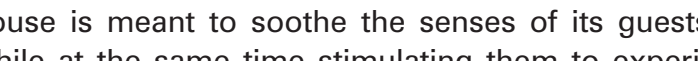
whem to experiwhesiding in the building. In order to provide the greatest possible comfort to people residing in such a hot climate, the design employs natural materials to prevent the building from overheating cause it to "breathe", protect against noise and prevent it from exerting any destructive impact on the surrounding environment. The use of straw as thermal insulation provided natural protection from wall overheating, which was further improved by the use of an air gap around the building as a thermal buffer. Straw is also an excellent acoustic insulator. The use of clay plaster was meant to provide breathing comfort thanks to natural humidity regulation within rooms. The texture of clay plasters, their shape and manner in which light falls on them affect the perception of the space. The design also utilises stone. Cool stone floor surfaces fluidly run from the external zone of the building to an interior courtyard. It was also essential to utilise the potential of the elevation and situate the complex on a terraced slope, with a view of the sea and the surroundings. Blending the guesthouse into its natural as well as cultural surrounding while respecting the local archetype was a highly of the builing and the use of the colour white. The author proposed a modern, minimalist interpretation of the Greek style in order to obtain a simple, yet sophisticated effect. A building utilising natural organic materials can also have a modern form. The massing was thus based on the clear proportions of the cube. In order to preserve the cohesion of the com plex, the shape of the square was also used in facade perforations and the internal courtyard. Setting the facade $50 \mathrm{~cm}$ away from the proper wall of the building was dictated primarily by practical considerations (a buffer air gap that protects against overheating), in addition to making it possible to obtain an effect of a sculpted cuboid. 
na $50 \mathrm{~cm}$ od ściany budynku miało przede wszystkim praktyczne uzasadnienie (buforowa pustka powietrzna chroniąca przed przegrzewaniem), ale także pozwoliło na uzyskanie efektu rozrzeźbionego kubika. Okna zagłebione są na $100 \mathrm{~cm}$ od zewnętrznej "skóry" budynku dzięki czemu elewacje budynku nie sprawiaja wrażeni płaskich.[6] Minimalistyczna ściana frontowa budynku sugeruje wejście do wewnatrz poprzez załamanie płasz czyzn, co tworzy intrygujacy rysunek świattocienia Bardziej dynamiczne sa elewacje południowa i wschodndzieki nieregularnemu rozmieszczziu różn wielkośc dziên nó o ru wy aje sie być przypadkowe. Defilowane jest przez mzieki tonstruck szy je

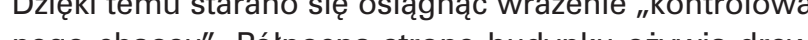
nego chaosu". Polnocną stronę budynku ožywia drewniany azur, doswe elewacji urozmaicona grą swiatta, kontrastuje z chropowatą strukturą kamienia na murkach iscianach najniższe kondygnacji. Calośc ma sprawiać wraženie spójnego, minimalistycznego i bezpretensionalnego założenia.

\subsection{Układ funkcjonalno-przestrzenny}

Kompleks obiektów ma w swoim założeniu przypisan główną funkcję rekreacyjno-szkoleniową. Projektowany budynek ma pełnic rolę pensjonatu i miejsca odpoczynk dla gości oraz uczestników różnego rodzaju warsztatów, dotyczących rzemiosła artystycznego czy naturalnego budownictwa. Przy kształtowaniu planów pensjonatu chodziło o to, by uzyskać płynne przenikanie się zewnętrznego otoczenia z wnętrzem obiektu. Szczególnie widać to na rzucie parteru, gdzie otwarte przez wszytskie kondygnacje patio pełni swego rodzaju strefę buforowa. Starano się stworzyć gradacje wejść do budynku oraz wykreować kameralne "wnetrze na zewnątrz". Zacieniony dziedziniec stanowi tez schro niec stazia przezywajoych w nim ludzi woda sptywowo

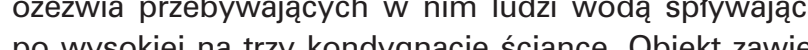

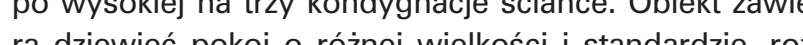

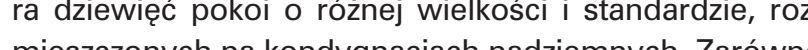
mieszczonych na kondy jajach większe apant na konty jak i miejsze pokoje wyposazon zostaly w ki schen. Do pokoi whodzi sie z galeri otwartej klatki schodowej. Z patio mozna się dostac do podziemne częsci budynku. Po prawej stronie po zejsciu ze schodów znajduje się strefa pomieszczen technicznych i porządkowych, niedostępna dla gości. Po lewej stronie mieści się pomieszczenie służące gościom jako przechowalnia bagażu. Idąc dalej korytarzem, można się dostać do baru i części rekreacyjnej z bilardem. Korytarz prowadzi też $\mathrm{n}$ zewnątrz budynku, na dziedziniec pomiędzy pensjonatem a tawerna, pełniący funkcję miejsca do przeprowadzani warsztatów.

\section{PODSUMOWANIE}

Technologia strawbale mimo, iż budzi wątpliwości i obawy, zyskuje sobie coraz więcej zwolenników. Obawy
The windows are set back by $100 \mathrm{~cm}$ from the external "skin" of the building, thanks to which cades do not give an impression of being flat [ 6 . The minimalist frontal wall of the building suggests the entrance of the building is located in a mutua shift of surfaces, which provides an intriguing outline of light and shadow. The southern and easter facades are more dynamic, thanks to an irregular placement of window openings. Window placement only appears to be random. It was defined by the structural frame module and the layout of rooms. The author wanted to create an impression of "controlled chaos" through this measure. The northern side of the building was enlivened with tio. The facade's mat intuces light to the pa-

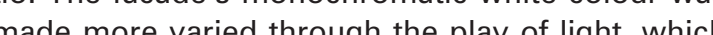
code more varied through the play of light, which fence and the walls of the lowest storeys. The enfor minimalist and unpretentious complex.

\subsection{Functional and spatial layout}

Thed a primary recreational and training function. The building that was designed is to play the role of a guesthouse and a place of rest for guests and participants of all manners of workshops on the subject of arts and crafts or natura construction. When designing the floor plans of the guesthouse, the main objective was to obtain a fluid gradient-like flow between the external surrounding and the building's interior. This is particularly visible on the ground floor plan, where the patio, which is open across all storeys, fulfils the role of a sort of buffer zone. An attempt was also made at introducing a gradation of entrances to the building and creat a cameral "interior exterior". The shaded courtyard also protects from the sun and refreshes the people inside thanks to water that flows down a three-storey-high wall.

The building features nine rooms with varying floor area and standard, placed in above-ground storeys. Both the larger apartments and smalle rooms were equipped with bathrooms, while mos also feature a kitchenette. Rooms are entered hrough an open stairwell's gallery. We can access patio. To the right side of the stairs there is a group f te. The righ be to guests. To the left there is a luggage storage space for guests. Going further down the corridor we can enter a bar and a recreational section with a pool table. The corridor also leads outside the building to the courtyard between the guesthouse and the tavern, which plays the role of a space for organising workshops.

\section{CONCLUSION}

Straw-bale technology, despite raising much doub and fear, is gaining an increasing amount of proponents. Fears are most often based on a lack of know- wynikają najczęściej z niewiedzy, więc zasadną jest tu edukacja dotycząca tego rodzaju budowania. Sciana $w$ technologii strawbale obustronnie otynkowana jest doskonałym izolatorem termicznym. Została również uznana jako materiał trudno zapalny (B1). Są też sprawdzone sposoby, dzięki którym można zapobiec problemom jej zawilgocenia. Słoma to materiał który po zakonczeniu użytkowania nadaje się do ponownego włạczenia w obieg materii, nie stanowi wiec odpadu jak standardowe tworzywa. Proces produkcji kostek stomy jak też ich transport, nie wymagaj tak dużych naktám enz ich jak w prypadku tradycyjnch miy naklów energi Je czynniki sprawiaja ze sposób wznoszeng budynć we czyniki sra we i pryjazny da uiytrownika. Edukacja w tym zakresie ska i prayjazny dla uzytkow ja. Edukacja w tym zakresie jest więc niezuykle cena. Pryllady studench projektów opracownych woparciu o te technologię moga stanowić doskonały materiał edukacyjny propagujący naturalne budownictwo.

PRZYPISY

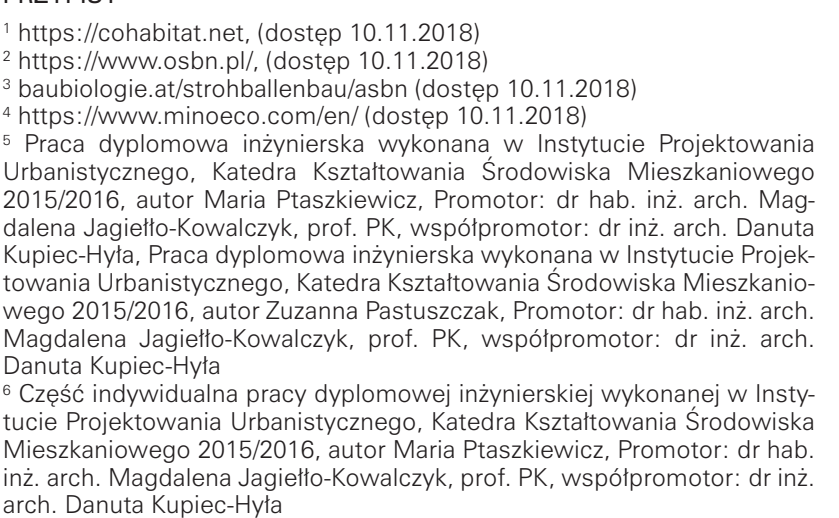

\section{BIBLIOGRAFIA}

11) Kalogiannaki E., Earth and Straw Constructions in Crete - Future po-
1entials, MSc Architecture: Advanced Energy and Environmental Studies,

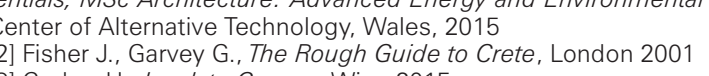

[3] Gruber H., Insulate Greece, Wien 2015 Minke G., Krick B., Podreccnnik budowania z kostek stomy, Fundacj Cohabitat, ,'́ódż, 2015 Mink G., Podrecznik budowania z gliny, Fundacja Cohabitat, tódż, 2015
[6] Pallasmaa J., Oczy skóry, Instytut Architektury, 2013
[7] Publikacia zbiorowa, Habitat start up kit, Fundacia Gos stracii Publicznej, Kraków, 2014

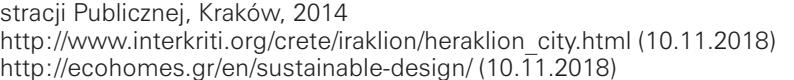
hitp:////ecohomos.gr/en/sustainable-desig//10
http://www.livingingreece.gr (10.11.2018) http: $/ /$ www.explorecrete.com/crete-archaeology-history.htm dostęp
10.11 .2018 http: ///Www.osbn.pl//(dostepp 10.11.2018)
https://cohabitat.net//(dostepp 10.11.2018

baubiologie.attstrohballenbau/asbn (dostep 10.11.2018
https://www.minoeco.com/en/(dostep 10.11.2018) edge, which is why education concerning this type of construction is justified. A wall made using strawbale technology that is plastered with clay on both sides is a perfect thermal insulator. It was also approved as a flame-retardant material (B1). There are also proven methods that can prevent the problem of it becoming damp. Straw is a material that can be reintroduced into the cycle of matter after use and does not constitute waste like standard materials do. The process of the production of straw bales, as well as their transport, does not require as much energy as in the case of traditional construction materials. These factors cause the process of erecting buildings in straw-bale technology to be environthus pard user valuable. Exation in this field is igns dever on the basis of this technology constitute perfect education material propagting natural construction.

ENDNOTES

https://cohabitat.net, (retrieved on 10.11.2018)
https://www osshn pol// (retrieved on 10.112018 baubiologie.at/strohballenbau/asbn (retrieved on 10.11.2018) Engineer's design project developed at the Institute of Urban De

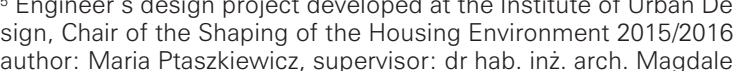

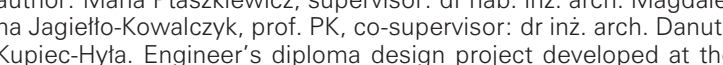
Institute of Urban Design, Chair of the Shaping of the Housing En-
vironment 2015/2016, author: Zuzanna Pastuszczak, supervisor: vironment 2015/2016, author: Zuzanna Pastuszczak, supervisor: dr
hab. inz. arch. Magdalena a agietto--Kowalczyk, prof. PK, co-supervi-
sor: dr inz. arch. Danuta Kupiec-yyła. 6 Individual section of engineer's diploma design project develo-
ped at the Institute of Urban Design, Chair of the Shaping of the Housing Environment 2015/2016, author: Maria Ptaskziewicz, su-
pervisor: dr hab. inz. arch. Magdalena Jagietto-Kowalczyk, prof. PK.

\section{BIBLIOGRAPHY}

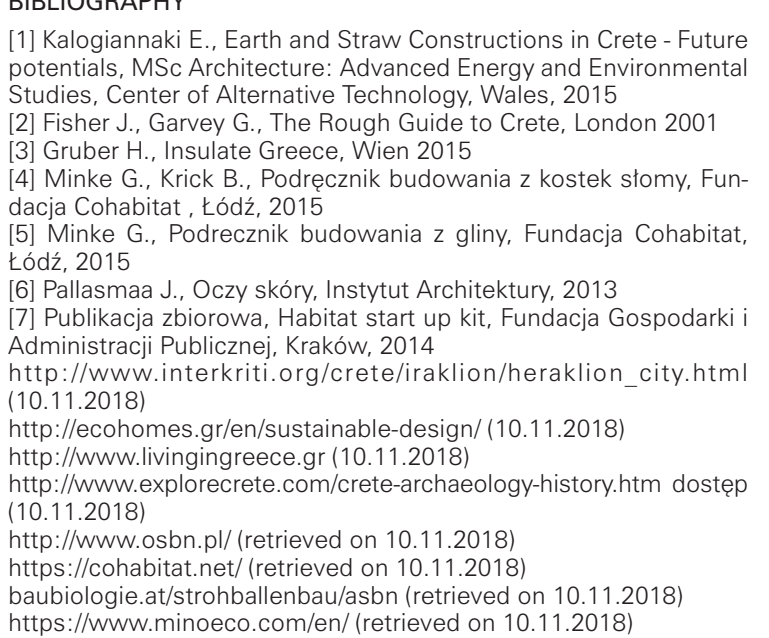


$G A$ B R I E L A , S G $\quad$ A R D E N

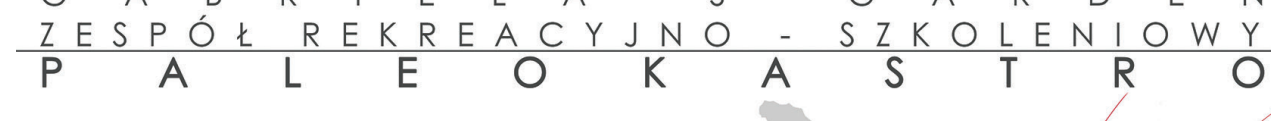
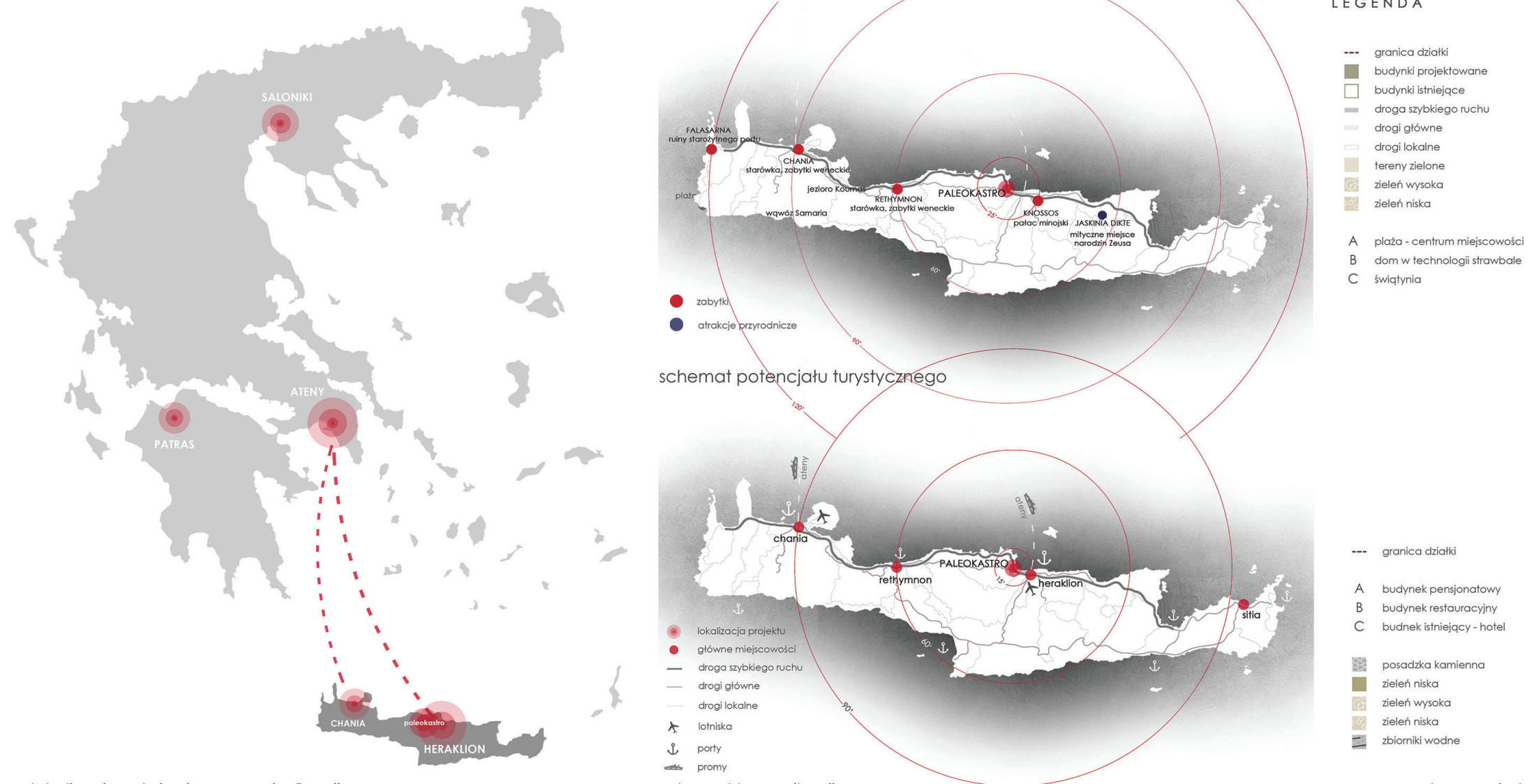

lokalizacja założenie w kontekście miejscowości skala 1:1000
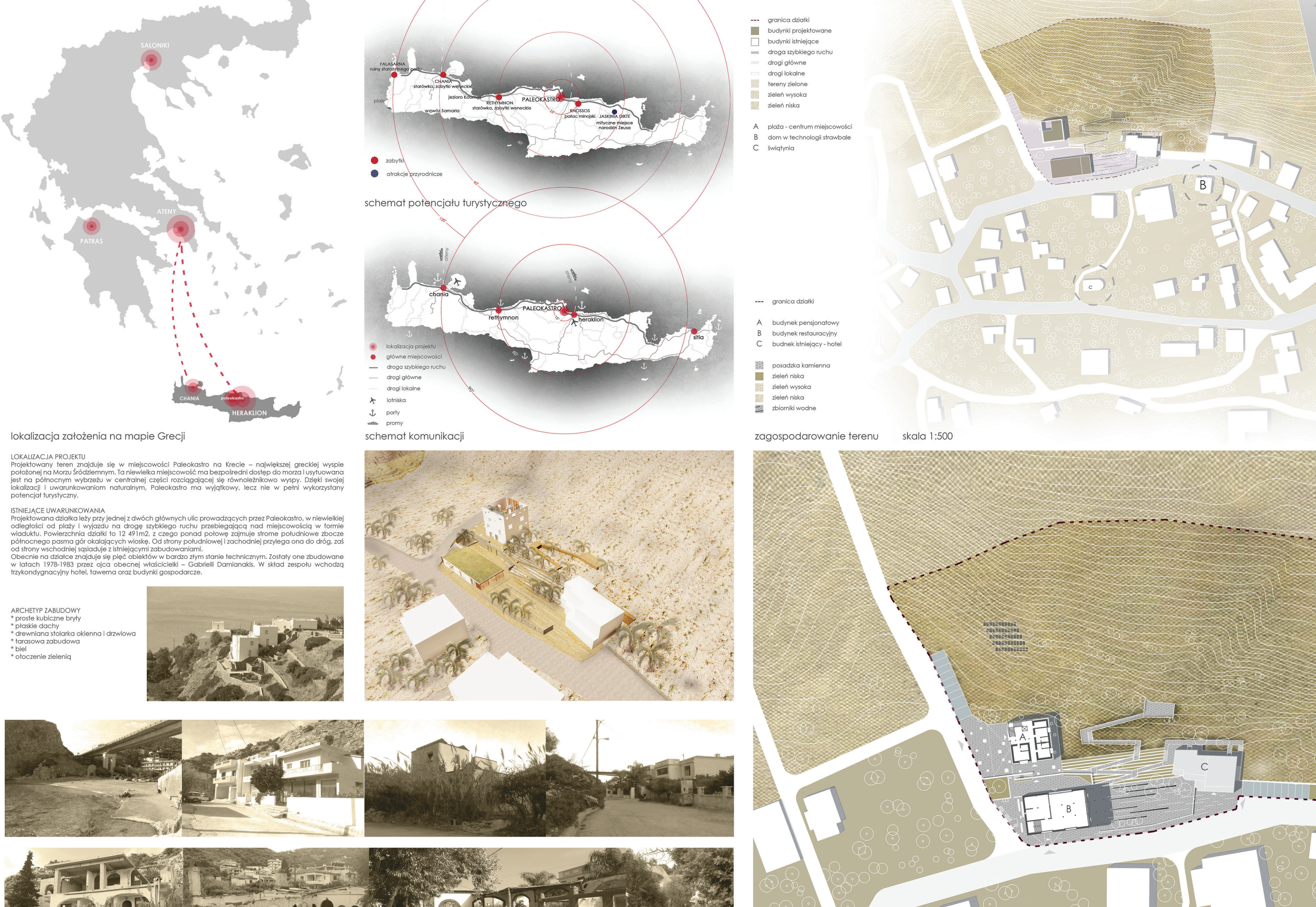

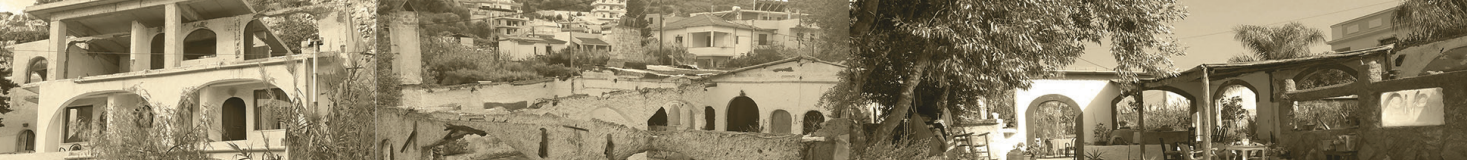
$\rightarrow$ in 4

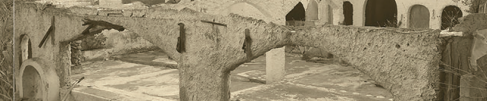

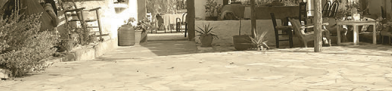

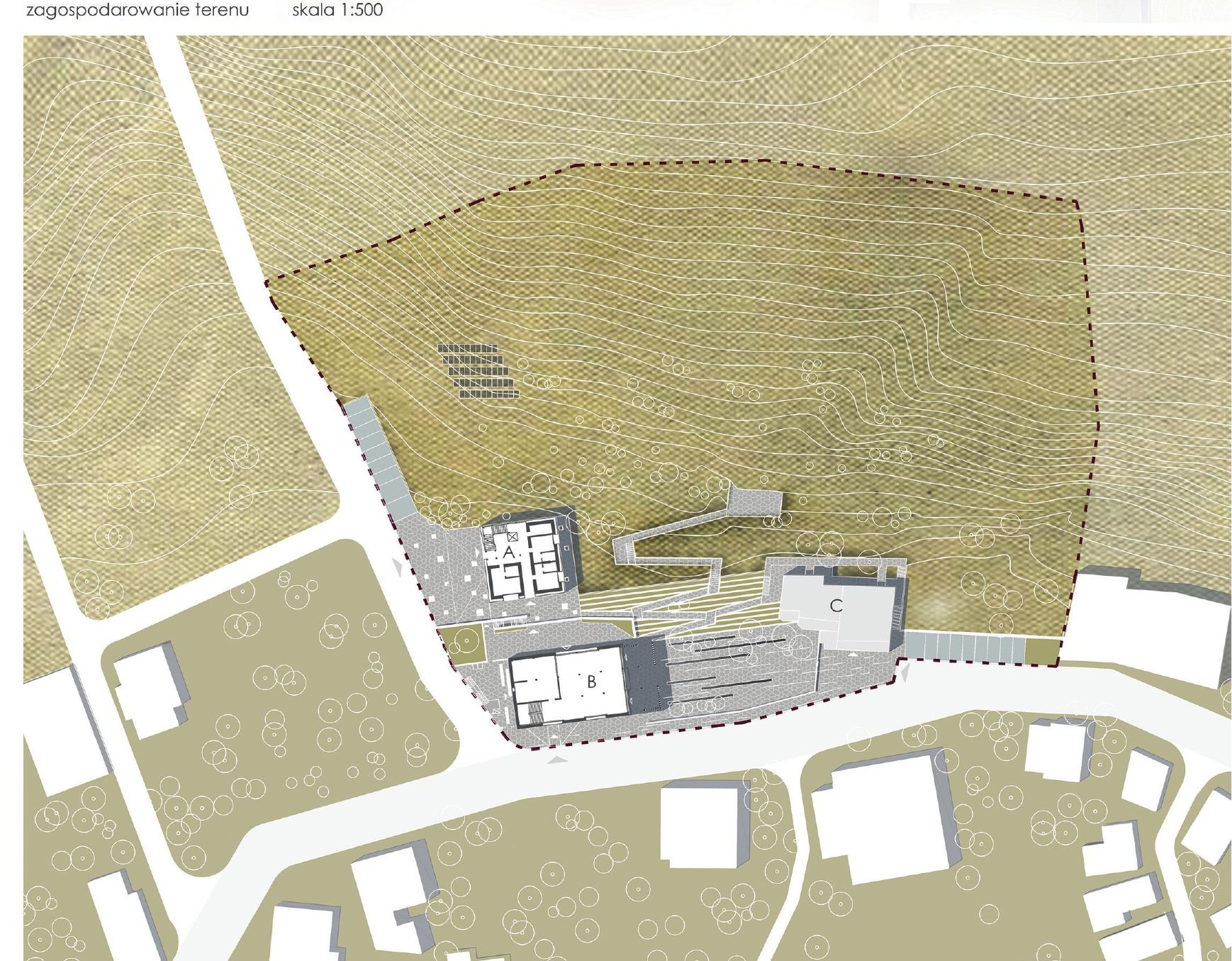




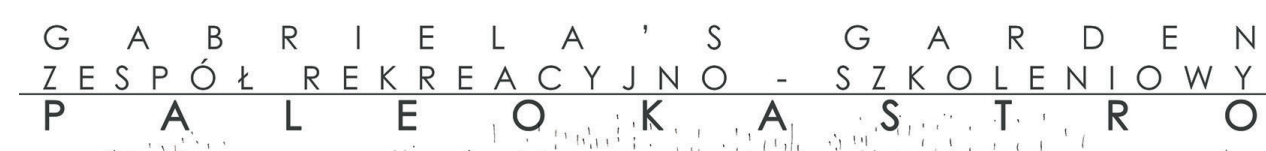
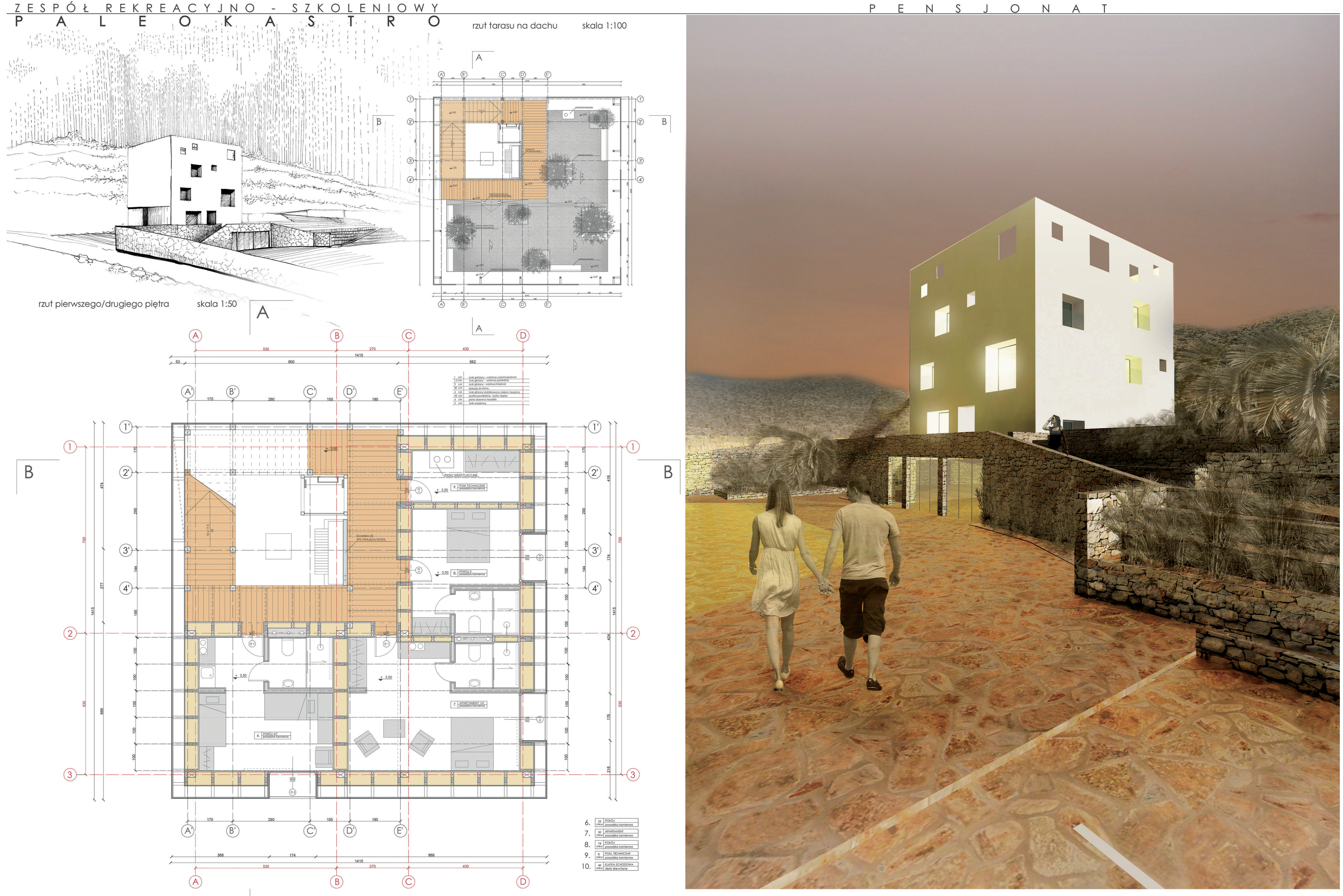

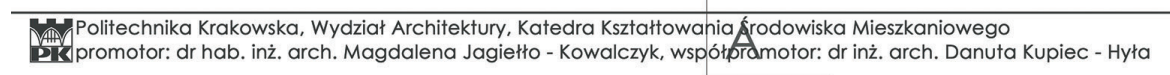




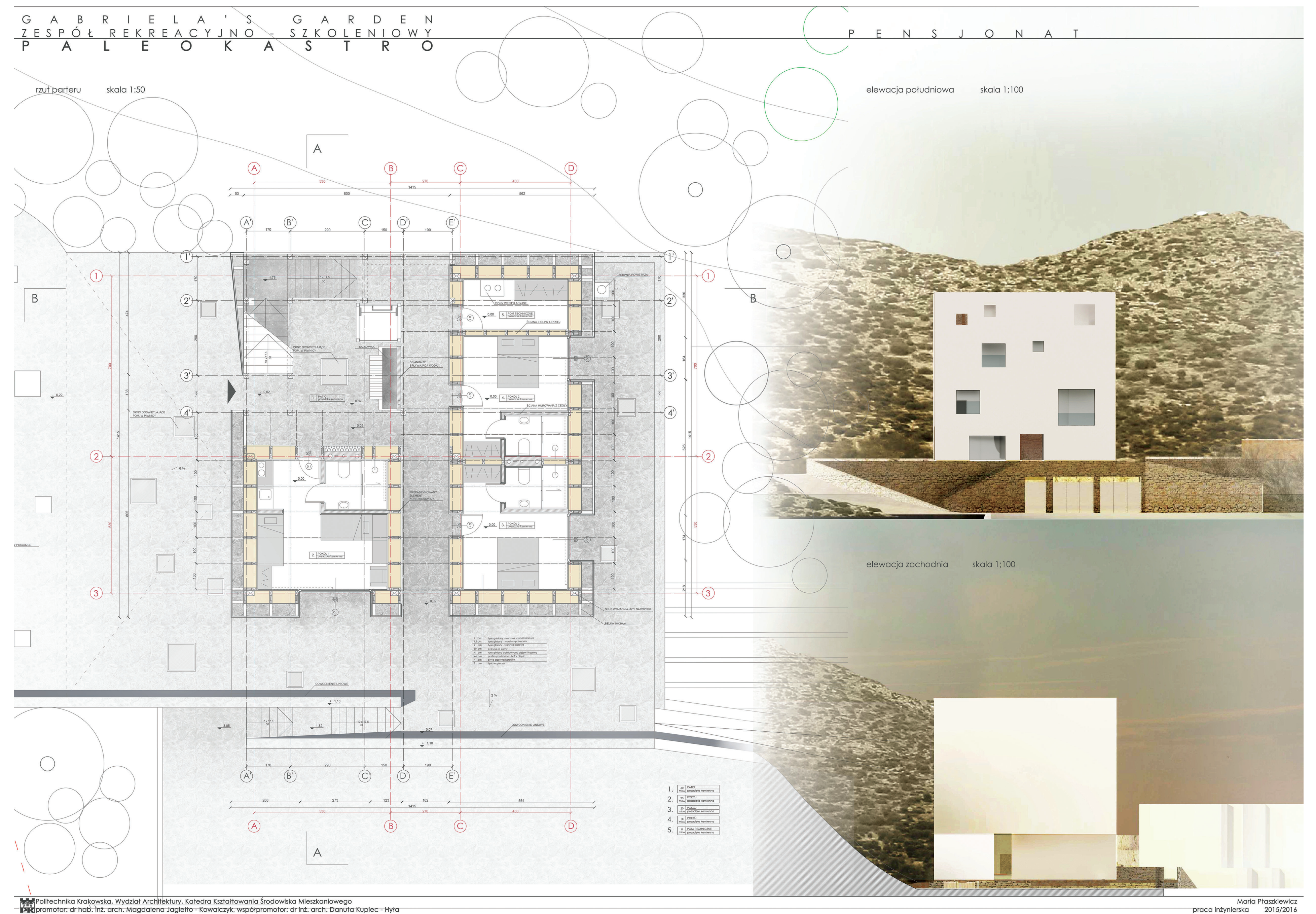

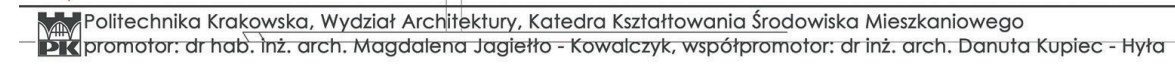




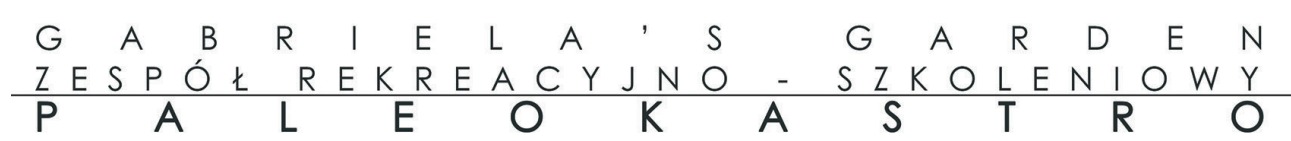

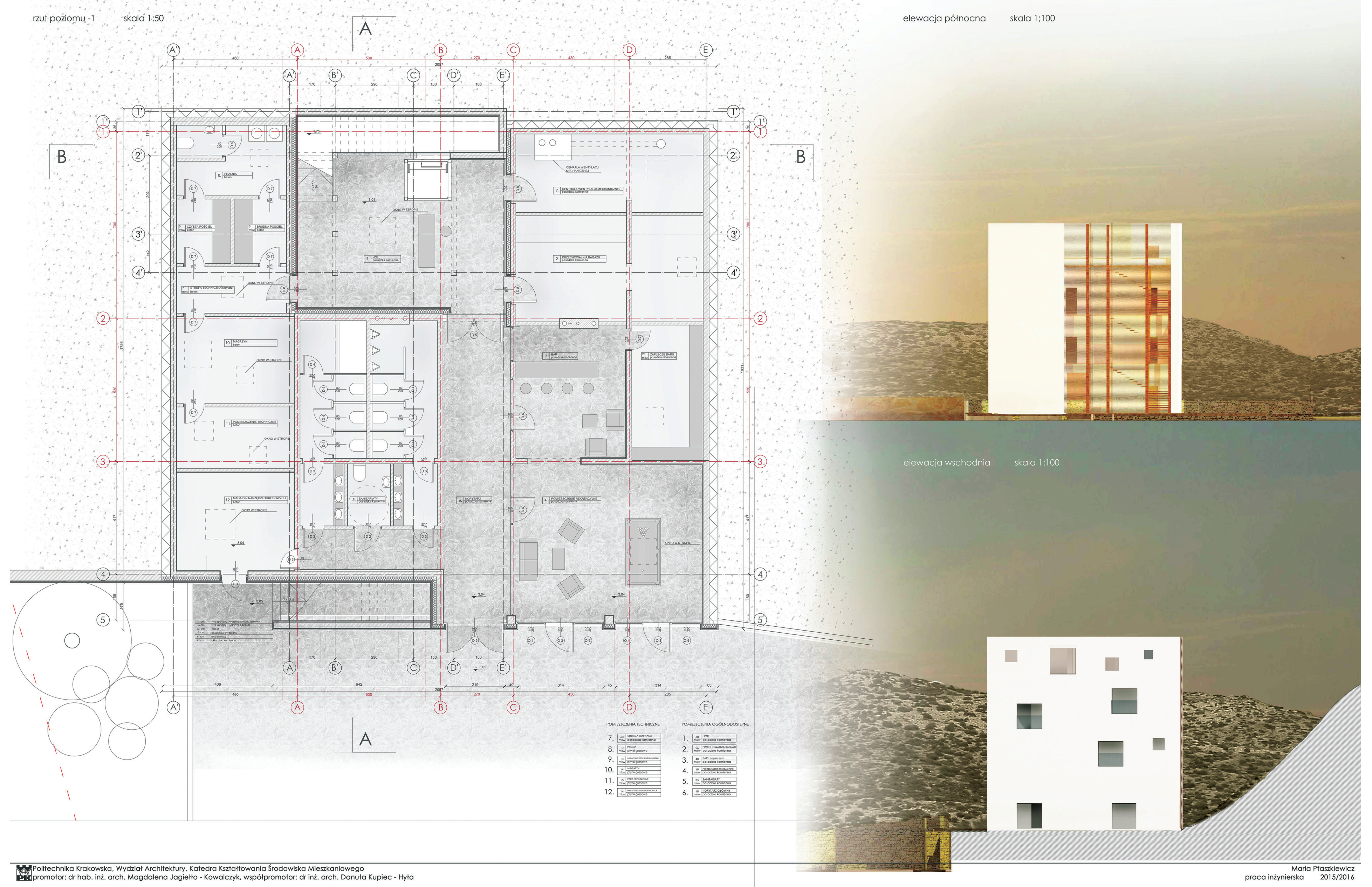




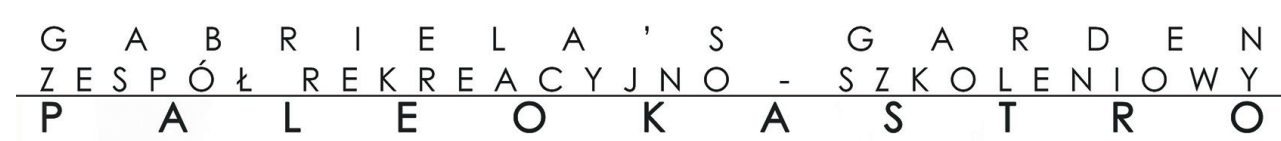

przekrój B-B skala 1:50

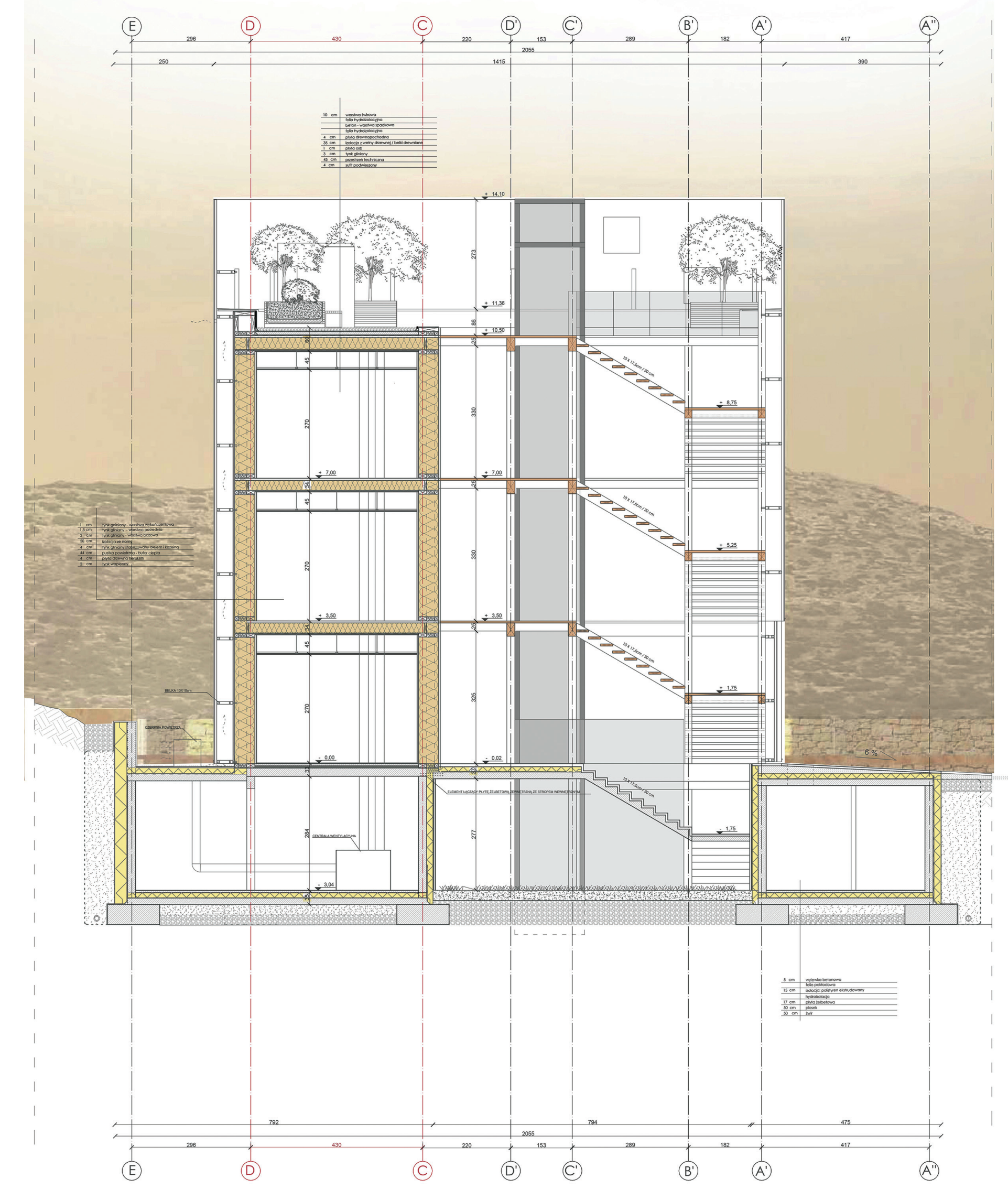

przekrój A-A skala 1:50

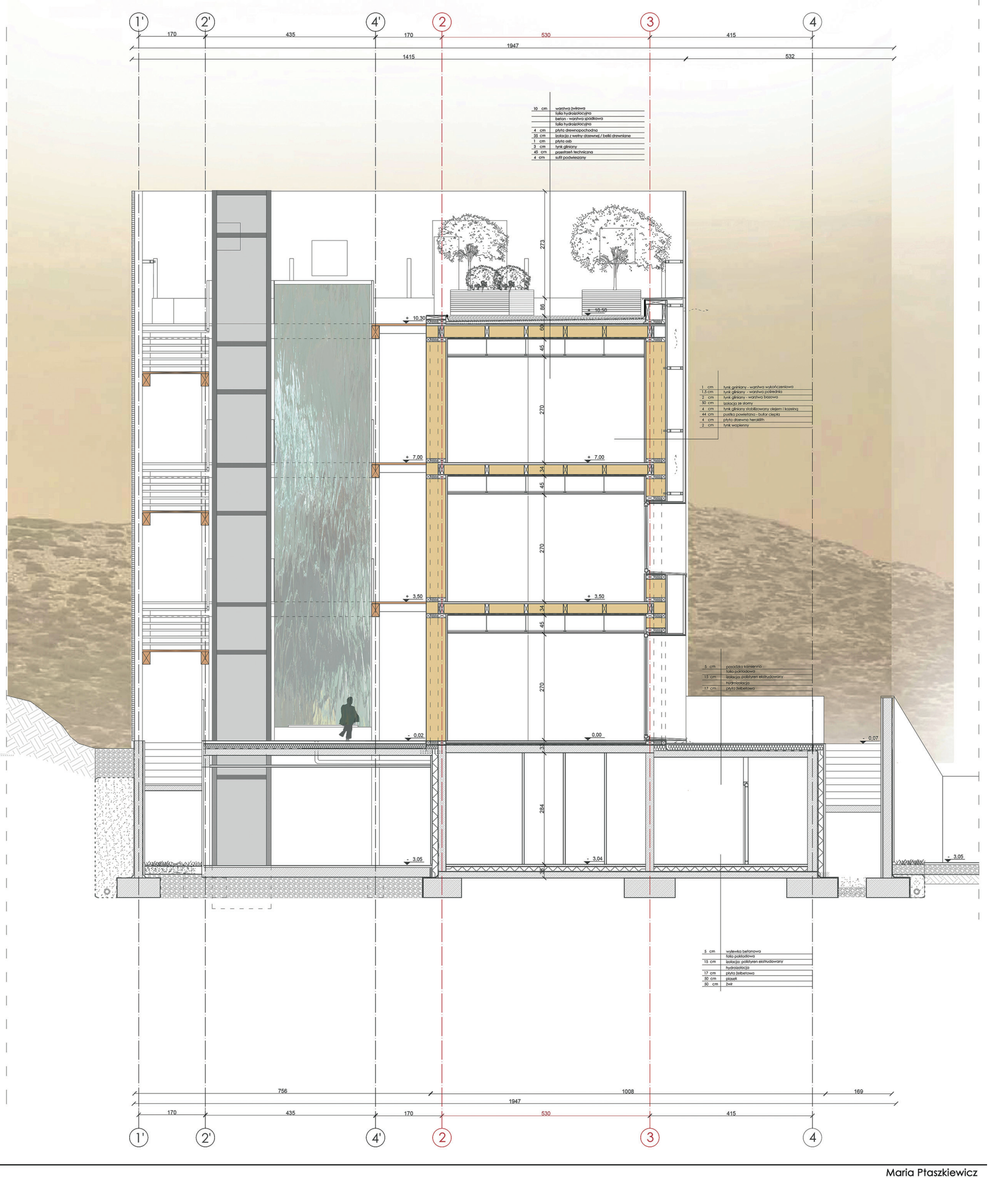




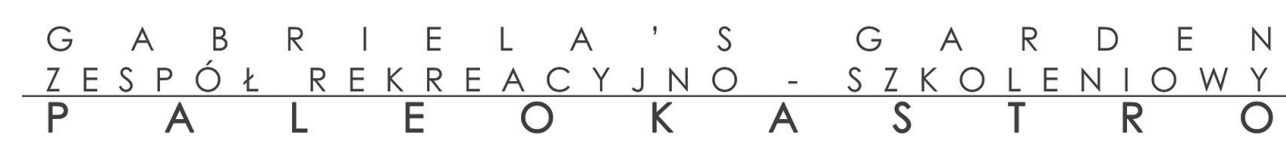

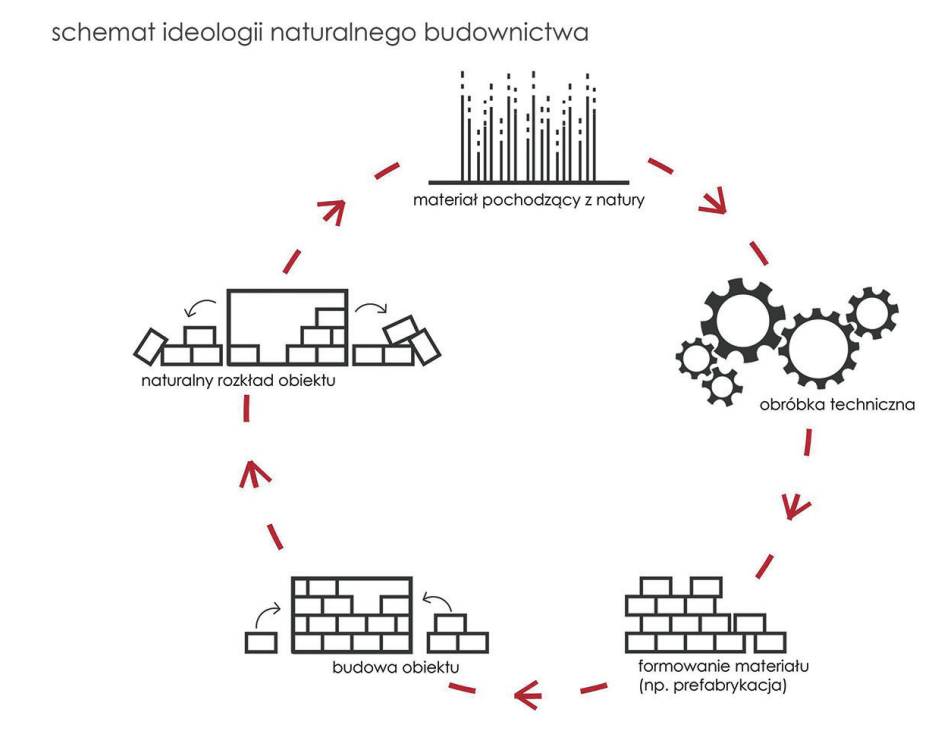

schamat funkcjonowania farmy stonecznej

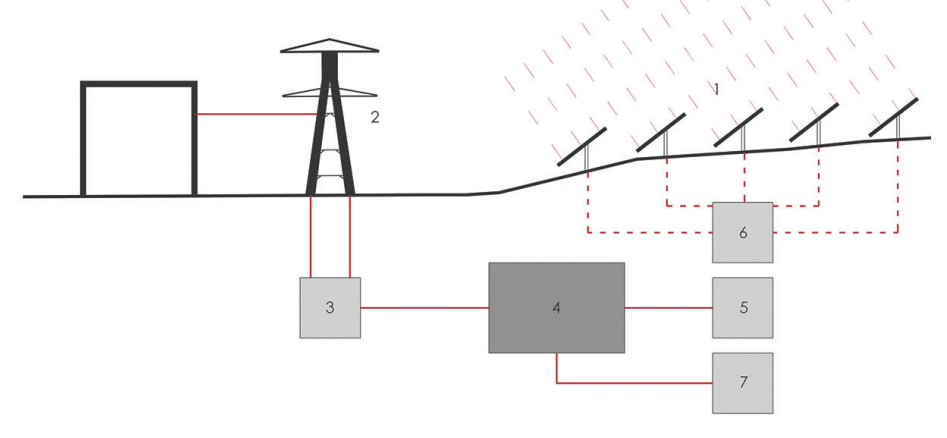

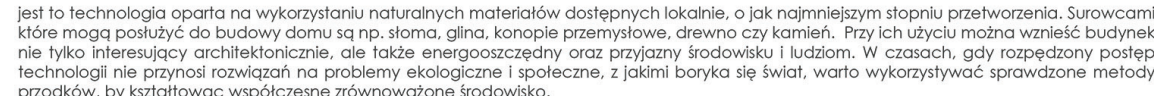
zaley noturanogos budownictwa

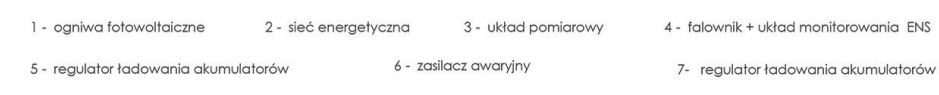

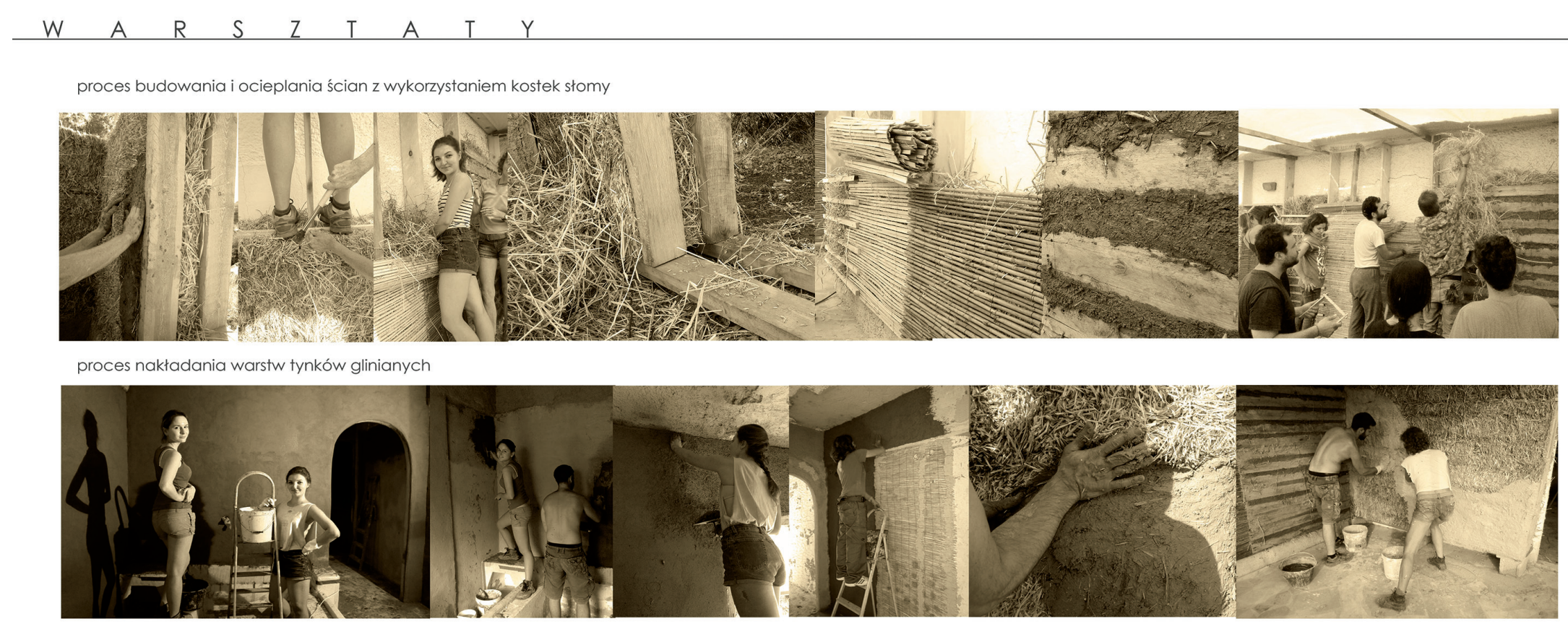
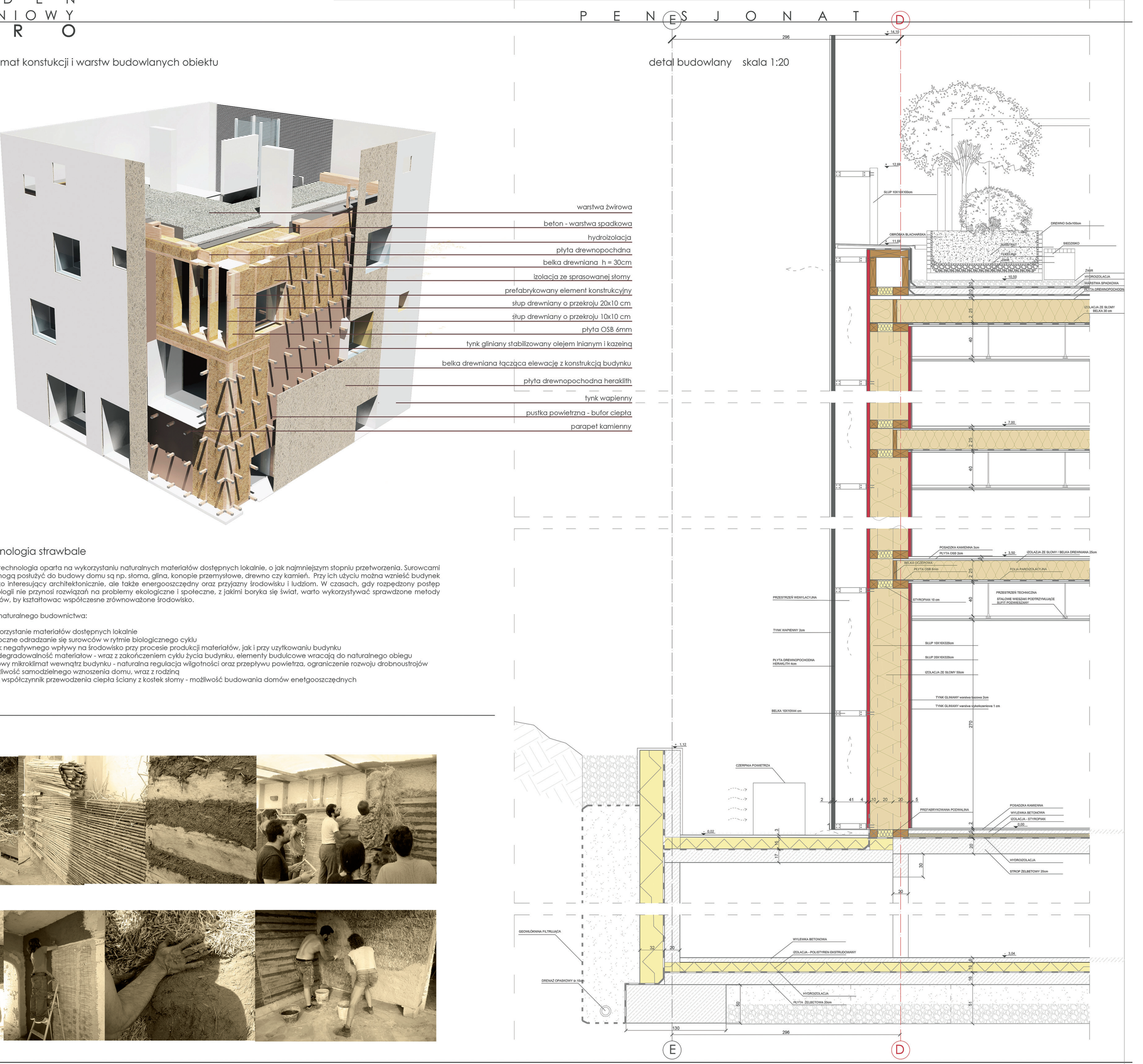

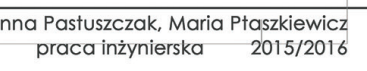

